\title{
Fluoride occurrence in the groundwater in a coastal region of Andhra Pradesh, India
}

\author{
N. Subba $\operatorname{Rao}^{1} \cdot$ P. Surya $\operatorname{Rao}^{1} \cdot$ A. Dinakar ${ }^{1}$ P. V. Nageswara Rao $^{2} \cdot$ \\ Deepali Marghade ${ }^{3}$
}

Received: 27 January 2015/Accepted: 27 August 2015/Published online: 18 September 2015

(C) The Author(s) 2015. This article is published with open access at Springerlink.com

\begin{abstract}
Fluoride $\left(\mathrm{F}^{-}\right)$content varies from 0.60 to $1.80 \mathrm{mg} / \mathrm{L}$ in the coastal region between Chirala and Ongole of Andhra Pradesh, India. It exceeds the threshold limit of $1.20 \mathrm{mg} / \mathrm{L}$ in $20 \%$ of the total groundwater samples. The aim of the present study is to assess the controlling factors of $\mathrm{F}^{-}$content. The study area experiences a dry climate and is underlain by Charnockite Group of rocks over which the river and coastal alluvium occur. The results of the study identify the four factors that control the high $\mathrm{F}^{-}$content. First one is related to alkalinity, leading to active dissolution and leaching of $\mathrm{F}^{-}$-bearing minerals, which supports the positive correlation of $\mathrm{F}^{-}$with $\mathrm{pH}$ and $\mathrm{HCO}_{3}{ }^{-}$. A longer water residence time in the clays is the second factor, which activates not only solubility and dissolution of $\mathrm{F}^{-}$-bearing minerals, but also anion exchange between $\mathrm{F}^{-}$and $\mathrm{OH}^{-}$. Third factor is a result of higher $\mathrm{Na}^{+}$ due to impact of saline water, ion exchange between $\mathrm{Na}^{+}$ and $\mathrm{Ca}^{2+}$, and precipitation of $\mathrm{CaCO}_{3}$. This reduces the $\mathrm{Ca}^{2+}$ content, causing dissolution of $\mathrm{CaF}_{2}$ to maintain the chemical equilibria, which is supported by positive correlation between $\mathrm{Na}^{2+}$ and $\mathrm{F}^{-}$. The influence of anthropogenic activities is the last factor, which acts as an additional source of $\mathrm{F}^{-}$. Thus, the shallow groundwater shows higher content of $\mathrm{F}^{-}$and the hydrogeochemical
\end{abstract}

N. Subba Rao

srnandipati@gmail.com

1 Department of Geology, Andhra University, Visakhapatnam 530003 , India

2 Department of Geology, Acharya Nagarjuna University, Nagarjunanagar, Guntur 522 510, India

3 Priyadarshini Institute of Engineering and Technology, Nagpur 440 019, India facies also support this hypothesis. The study suggests the remedial measures to reduce the $\mathrm{F}^{-}$content.

Keywords Fluoride - Groundwater - Coastal region · Prakasam district $\cdot$ Andhra Pradesh · India

\section{Introduction}

Groundwater is a major source for drinking as well as for agricultural and industrial use. In India, the people suffer mainly from two health disorders due to occurrences of fluoride $\left(\mathrm{F}^{-}\right)$and arsenic (As) in drinking water. Relatively, the health implications caused by $\mathrm{F}^{-}$-contamination are far more wide spread than those of As contamination in the country (Subba Rao 2011). Approximately, 62 million people, including 6 million children suffer from fluorosis in the country due to consumption of $\mathrm{F}^{-}$-contaminated water (Susheela 1999). The endemic fluorosis is prevalent in many states, including Andhra Pradesh, Bihar, Delhi, Gujarat, Haryana, Karnataka, Madhya Pradesh, Maharastra, Odisha, Punjab, Rajasthan, Tamil Nadu, Telangana (a part of erstwhile Andhra Pradesh) and Uttar Pradesh in the country.

Many investigations on geochemistry of $\mathrm{F}^{-}$-bearing groundwater have been carried out in different parts of the world. A detailed study on geochemistry and genesis of $\mathrm{F}^{-}$-containing groundwater in different geological formations of India has been done by Handa (1975), Sahu and Karim (1989), Jacks et al. (1993, 2005), Datta et al. (1996), Agrawal et al. (1997), Gupta et al. (1999, 2005), Das et al. (2003), Chakraborti et al. (2000), Bhosle et al. (2001), Ray et al. (2000), Madhavan and Subramanian (2002), Muralidharan et al. (2002), Ayoob and Gupta (2006), Misra and Mishra (2006), Kundu and Mandal (2009a, b), Raju 
et al. (2009) and Vikas et al. (2009). Jha and Jha (1982) explain the natural sources as responsible for $\mathrm{F}^{-}$contamination in India that causes serious health problems. Ramesam and Rajagopalan (1985) report that the degree of weathering and the leachable $\mathrm{F}^{-}$in a hard rock terrain is more important in deciding $\mathrm{F}^{-}$content in the water rather than the mere presence of $\mathrm{F}^{-}$-bearing minerals in the bulk rocks/soils. Fluoride-bearing minerals (fluorite, apatite, biotite, hornblende, etc.) present in hard rock terrains (basalts, granites, gneisses, schists, charnockites, khondalites, etc.) and anthropogenic sources (chemical fertilisers, sewage, sludge, etc.) in India are mainly responsible for higher content of $\mathrm{F}^{-}$in groundwater with a combination of higher rate of evaporation and longer interaction of water with aquifer materials under alkaline environment (Ramamohana Rao et al. 1993; Wodeyar and Sreenivasan 1996; Chatterjee and Mohabey 1998; Subba Rao et al. 1998a, b, 2012; Sumalatha et al. 1999; Kundu et al. 2001; Saxena and Ahmed 2003; Subba Rao 2003, 2009, 2011; Subba Rao and John Devadas 2003; Subba Rao and Rao 2003; Sujatha 2003; Bhagavan and Raghu 2005; Sreedevi et al. 2006; Madhnure et al. 2007; Shaji et al. 2007; Srinivasamoorthy et al. 2008, 2012; Ramachandran et al. 2012; Reddy et al. 2010; Deepu and Shaji 2011; Chidambaram et al. 2013; Manikandan et al. 2014). All these studies state that high $\mathrm{F}^{-}$and very low $\mathrm{Ca}^{2+}$ and $\mathrm{Mg}^{2+}$ or inverse relation between $\mathrm{F}^{-}$and $\mathrm{Ca}^{2+}$ or $\mathrm{Mg}^{2+}$ in water are a result of higher $\mathrm{Na}^{+}$(due to impact of saline water), prior precipitation of $\mathrm{CaCO}_{3}$ from water and a limited incorporation of $\mathrm{F}^{-}$in $\mathrm{CaCO}_{3}$ structure so that there is always a net balance of $\mathrm{F}^{-}$in solution. They also discuss the role of clays that facilitate active solubility and dissolution of $\mathrm{F}^{-}$containing minerals, and also activate anion exchange between $\mathrm{F}^{-}$and $\mathrm{OH}^{-}$. Further, they also explain that high $\mathrm{F}^{-}$groundwater is associated with high $\mathrm{HCO}_{3}{ }^{-}, \mathrm{Na}^{+}, \mathrm{K}^{+}$, $\mathrm{SO}_{4}{ }^{2-}$ and $\mathrm{NO}_{3}{ }^{-}$ions. Gao et al. $(2007,2013)$ point out the processes of $\mathrm{F}^{-}$activity reduction and the change of ratio $\mathrm{Na}^{+}: \mathrm{Cl}^{-}$in the groundwater induced by intrusion of saline water, which favours dissolution of $\mathrm{F}^{-}$-bearing minerals at the salt lake area of Yuncheng basin, Northern China. Singaraja et al. (2013), Subba Rao et al. (2014a, b) and Surya Rao et al. (2015) state that the higher $\mathrm{Na}^{+}$and $\mathrm{pH}$ causing factor for release of $\mathrm{F}^{-}$into the groundwater is due to the influence of saline water in coastal aquifers of South India.

In Andhra Pradesh, the highest $\mathrm{F}^{-}$-affected villages are approximately 195 in Prakasam district (Eenadu 2013). The first case of endemic fluorosis in the country was reported as long as 1937 in the district (a part of erstwhile Guntur district; Shortt et al. 1937). There are so many unnoticed $\mathrm{F}^{-}$-contaminated groundwater areas in the district, in which the coastal region of Chirala-Ongole is no exception (Fig. 1). The controlling factors of $\mathrm{F}^{-}$content in

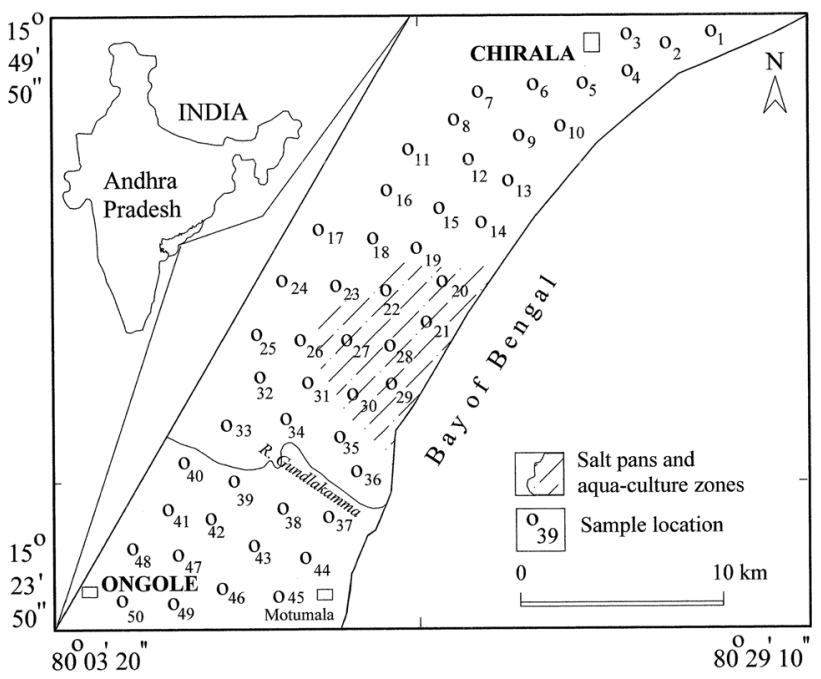

Fig. 1 Location of the coastal region between Chirala and Ongole, Prakasam District, Andhra Pradesh, India

the groundwater are not uniform in any area. Thus, the coastal region between Chirala and Ongole is chosen for the present study to assess the controlling factors of $\mathrm{F}^{-}$. bearing groundwater and also to suggest the suitable remedies to reduce the $\mathrm{F}^{-}$-content in the drinking water before one can act intelligently towards the aim of improvement in water quality as well as in health conditions.

\section{Study area}

\section{Location}

The study area lies in between $80^{\circ} 29^{\prime} 10^{\prime \prime}-80^{\circ} 03^{\prime} 20^{\prime \prime}$ East and $15^{\circ} 23^{\prime} 50^{\prime \prime}-15^{\circ} 49^{\prime} 50^{\prime \prime}$ North with a linear patch extending for about $10 \mathrm{~km}$ from the sea coast and covering nearly $40 \mathrm{~km}$ in the north-south direction along the coast (Fig. 1). It covers an area of $400 \mathrm{~km}^{2}$. The area experiences a dry climate, with an annual average temperature of $19.7^{\circ}$ to $41.7^{\circ} \mathrm{C}$ and receives an annual rainfall of about $900 \mathrm{~mm}$. The southwest monsoon (June to September) contributes $44 \%$ (396 mm), the northeast monsoon (October to December) $50 \%(450 \mathrm{~mm})$ and the non-monsoon (January to May) the remaining $6 \%(54 \mathrm{~mm})$ of the total rainfall. Cyclones/depressions are not uncommon. The river Gundalakamma drains the area (Fig. 2).

\section{Geology}

The slope of the study area is gentle towards the southeast. The soils are of silty clay, sand and black cotton types. The sand is dominant in the northern part. The proportion of clay content (silty clay and black cotton soils) increases 
towards the southern part from the northern part. The occurrence of kankar (concretion of $\mathrm{CaCO}_{3}$ ) in the soil zone is a characteristic feature of dry climate. The southern part of the study area is underlain by Charnockite Group of rocks of the Archaean and the rest of the part by the river and coastal alluvium of the Recent (Fig. 3). Apatite, hornblende and biotite are the main $\mathrm{F}^{-}$-bearing minerals in the host rocks, which occur in and around Ongole.

The sub-surface geology reveals fine, fine to medium and medium sand at depths of less than 0.50, 0.50-16 and 16-22 $\mathrm{m}$ from the ground surface, respectively, at Chirala; and fine sand with clay from a depth of less than $3 \mathrm{~m}$, followed by fine to medium sand with clay, quartzite pieces with clay and kankar, gravel with sand and clay, and clay with fine sand from depths of 3-10, 10-34, 34-64 and 64-174 $\mathrm{m}$ from the surface, respectively, at Motumala

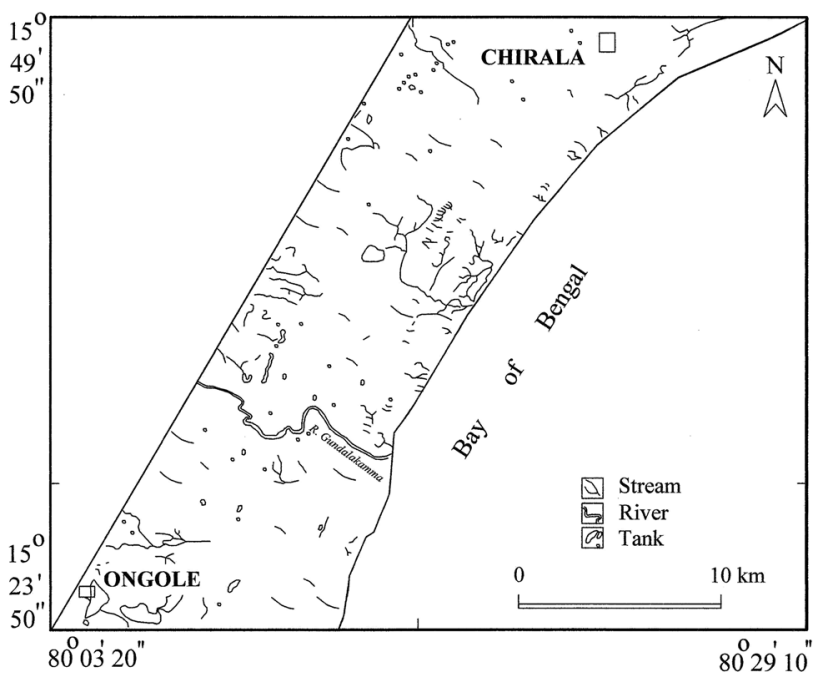

Fig. 2 Drainage of the study area

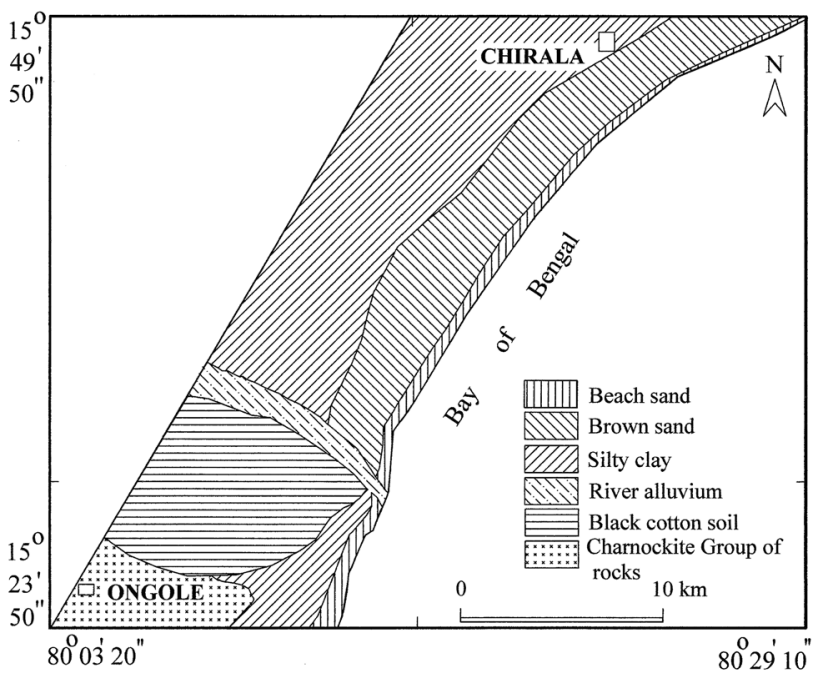

Fig. 3 Geology map of the study area
(CGWB 2002). As per the well owners, the depth of weathering varies from 1 to $5 \mathrm{~m}$ and fracturing extends up to depth of $30 \mathrm{~m}$, which are not uniform in their horizontal and vertical variation.

\section{Hydrogeology}

Groundwater is used for drinking and irrigation purposes in the study area. It occurs under unconfined and semi-confined to confined conditions. The water level varies from 7.50 to $13.60 \mathrm{~m}$ below ground level (bgl) and the direction of water flow being towards the eastern side (Fig. 4). The occurrence of sand in the northern part develops a good drainage conditions by virtue of its high hydraulic conductivity, while in the southern part the content of clay increases gradually from the northern part, which forms a sluggish drainage condition due to its low hydraulic conductivity. In addition to this, the presence of rocks in the southern part has low hydraulic conductivity, because of limited weathered and fractured portions, which form a poor drainage conditions. The yield is from 215 to $300 \mathrm{~m}^{3} /$ day in filter points/tube wells observed from the area of river alluvium, while it is from 40 to $100 \mathrm{~m}^{3} /$ day in bore wells in the area of rock terrain (CGWB 2013). The transmissivity is in the range of $30-1400 \mathrm{~m}^{2} /$ day in the former area, while it is $1-12 \mathrm{~m}^{2} /$ day in the latter area. It indicates that the movement of groundwater flow is slow in the rock terrain.

\section{Sources of pollution}

Dry climate and the occurrence of clay in the soil zone as well as in the sub-surface at different depths cause salinity (which occurs naturally in the geological formations) in the

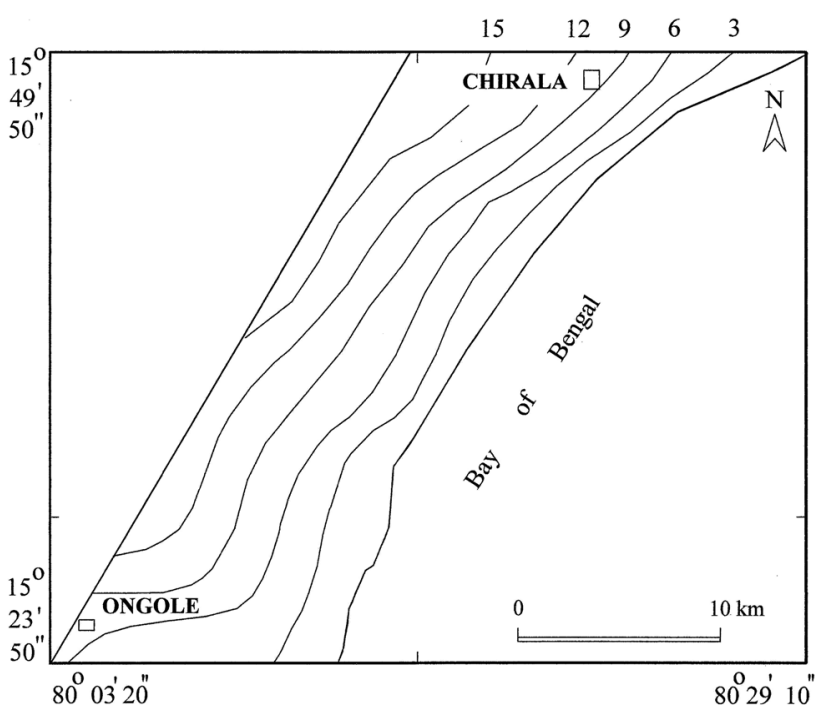

Fig. 4 Depth to groundwater level (m bgl) in the study area 
study area (Subba Rao 2014; Subba Rao et al. 2014a, b). Irrigation is intensive and long-term practice, leading to groundwater contamination due to irrigation return flows. Applications of agricultural fertilisers like nitrogen, phosphate and potash varieties, and soil amendments (gypsum) are unlimited for higher crop growth of tobacco, paddy, cotton, groundnut, pulses, etc., causing a deterioration of groundwater quality. Salt pans and aqua-cultural activities are dominant in the central part of the study area (Fig. 1), which are the sources of salinity in the groundwater. Sanitary facilities, such as dumping of domestic wastes and leakage of septic tanks, are poor. They also cause groundwater pollution.

\section{Materials and methods}

Water samples from 50 open dug wells were collected in half-litre polythene bottles, after the bottles were soaked in $1: 1 \mathrm{HCl}$ for $24 \mathrm{~h}$ and were rinsed with distilled water followed by deionised water, during summer 2011 (Fig. 1). The bottles were tightly capped without air gap. Immediately, after collection of the water, the samples are shifted to laboratory for the chemical analysis, following the standard water quality procedures (APHA 1999).

The values of $\mathrm{pH}$ and electrical conductivity (EC) were measured in the field, using their portable meters (Systronics make). The EC was used to calculate the total dissolved solids (TDS), following the procedure suggested by Hem (1991). Total hardness (TH) as $\mathrm{CaCO}_{3}$ and calcium $\left(\mathrm{Ca}^{2+}\right)$ were estimated by volumetric titrations, using standard EDTA. Bicarbonate $\left(\mathrm{HCO}_{3}{ }^{-}\right)$and chloride $\left(\mathrm{Cl}^{-}\right)$ were analysed volumetrically, using standard $\mathrm{HCl}$ and $\mathrm{AgNO}_{3}$, respectively. Magnesium $\left(\mathrm{Mg}^{2+}\right)$ was computed, taking the difference between $\mathrm{TH}$ and $\mathrm{Ca}^{2+}$. Sodium $\left(\mathrm{Na}^{+}\right)$ and potassium $\left(\mathrm{K}^{+}\right)$were analysed using flame photometer. Sulphate $\left(\mathrm{SO}_{4}{ }^{2-}\right)$, nitrate $\left(\mathrm{NO}_{3}{ }^{-}\right)$and fluoride $\left(\mathrm{F}^{-}\right)$, using turbidimetric, colorimetric and ion-selective electrode methods, respectively. All chemical variables (except $\mathrm{pH}$ ) are expressed in milligrams per litre $(\mathrm{mg} / \mathrm{L})$ and also in milliequivalents per litre (me/L).

The analytical precision for the chemical variables was determined by the ionic balance computed between cations $\left(\mathrm{Ca}^{2+}, \mathrm{Mg}^{2+}, \mathrm{Na}^{+}\right.$and $\left.\mathrm{K}^{+}\right)$and anions $\left(\mathrm{HCO}_{3}{ }^{-}, \mathrm{Cl}^{-}\right.$, $\mathrm{SO}_{4}{ }^{2-}, \mathrm{NO}_{3}{ }^{-}$and $\mathrm{F}^{-}$) as $100 \times($ cations - anions)/(cations + anions). This is within the acceptable limit of $\pm 5 \%$ (Deutsch 1997).

\section{Results and discussion}

The $\mathrm{pH}$ varies from 7.2 to 8.2 , being an average of 7.81 (Table 1), indicating an alkaline nature of groundwater. The TDS ranges from 850 to $3380 \mathrm{mg} / \mathrm{L}$ and its average is
$1745.80 \mathrm{mg} / \mathrm{L}$. The groundwater belongs to fresh (TDS $<1000 \mathrm{mg} / \mathrm{L}$ ) in $22 \%$ and brackish (TDS $1000-10,000 \mathrm{mg} / \mathrm{L}$; Fetter 1990) in $78 \%$ of the total samples. The concentrations $(\mathrm{mg} / \mathrm{L})$ of $\mathrm{Ca}^{2+}, \mathrm{Mg}^{2+}, \mathrm{Na}^{+}$, $\mathrm{K}^{+}, \mathrm{HCO}_{3}{ }^{-}, \mathrm{Cl}^{-}, \mathrm{SO}_{4}{ }^{2-}, \mathrm{NO}_{3}{ }^{-}$and $\mathrm{F}^{-}$vary from 30 to 75 , $40-180,165-746,8-110,310-550,180-1325,12-232$, $39-123$ and $0.60-1.80$ with an average of $48.60,80.90$, 399.12, 29.34, 429.00, 623.30, 88.40, 51.84 and 0.98, respectively.

As per the TDS classification (Table 2; Fig. 4), two hydrogeochemical facies, viz., $\mathrm{Na}^{+}>\mathrm{Mg}^{2+}>\mathrm{Ca}^{2+}$ : $\mathrm{HCO}_{3}{ }^{-}>\mathrm{Cl}^{-}>\mathrm{SO}_{4}{ }^{2-}$ (where the TDS is less than $1000 \mathrm{mg} / \mathrm{L})$ and $\mathrm{Na}^{+}>\mathrm{Mg}^{2+}>\mathrm{Ca}^{2+}: \quad \mathrm{Cl}^{-}>$ $\mathrm{HCO}_{3}{ }^{-}>\mathrm{SO}_{4}{ }^{2-}$ (where the TDS is more than $1000 \mathrm{mg} / \mathrm{L}$ ) are observed from the study area. The facies is useful for determining the flow pattern and origin of chemical histories of groundwater masses. Thus, the $\mathrm{pH}, \mathrm{Ca}^{2+}, \mathrm{Mg}^{2+}$, $\mathrm{Na}^{+}, \mathrm{K}^{+}, \mathrm{HCO}_{3}{ }^{-}, \mathrm{Cl}^{-}, \mathrm{SO}_{4}{ }^{2-}, \mathrm{NO}_{3}{ }^{-}$and $\mathrm{F}^{-}$increase with the increase of TDS (Fig. 5).

A higher $\mathrm{Na}^{+}$indicates dissolution of minerals and/or soil salts as well as the influence of anthropogenic and marine sources (Todd 1980; Stallard and Edmond 1983; Subba Rao 2002, 2014; Subba Rao et al. 2014a, b). A dominance of $\mathrm{HCO}_{3}{ }^{-}$favours mineral dissolution (Stumm and Morgan 1996). An abundance of $\mathrm{Cl}^{-}$is a result of leaching from soils and the influence of domestic wastes, salt pans, aqua-cultural activities, etc. (Todd 1980; Subba Rao 2014). Further, the solubility of $\mathrm{Na}^{+}$and $\mathrm{Cl}^{-}$is high (Hem 1991; Drever 1997). Sulphate and $\mathrm{NO}_{3}{ }^{-}$are the sources of soils, evaporites, fertilisers, domestic wastes, leakage of septic tanks, etc. (Todd 1980; Drever 1997; Subba Rao 2014). Ferromagnesian minerals and manmade activities (salt pans and aqua-cultural activities) are responsible for higher $\mathrm{Mg}^{2+}$ than $\mathrm{Ca}^{2+}$ in the groundwater (Hem 1991; Drever 1997; Subba Rao 2014; Subba Rao et al. 2014a, b). A lower $\mathrm{K}^{+}$indicates its lower geochemical mobility and its absorption on clays (Hem 1991; Drever 1997). Fluoride minerals, agro-chemicals, etc., are the sources of $\mathrm{F}^{-}$in the groundwater (Ayoob and Gupta 2006; Ahmed 2014; Rao et al. 2014).

In the present study area (Table 1), the concentration of $\mathrm{F}^{-}$exceeds $1.20 \mathrm{mg} / \mathrm{L}$ in $20 \%$ of the total groundwater samples $(18,20-24,28,29,49$ and 50). According to ISI (2012) and WHO (2008), the desirable and permissible limits of $\mathrm{F}^{-}$in drinking water are 1.00 and $1.50 \mathrm{mg} / \mathrm{L}$, respectively. However, the recommended limit of $\mathrm{F}^{-}$in the water depends on the climatic conditions of an area (USPHS 1987), because the amount of water consumed and the amount of $\mathrm{F}^{-}$ingested is influenced primarily by air temperature. Thus, the higher the air temperature, the lower is the allowable concentration of $\mathrm{F}^{-}$. On the other hand, the intake of $\mathrm{F}^{-}$below $0.50 \mathrm{mg} / \mathrm{L}$ causes dental caries (WHO 2008), while it is above $1.00 \mathrm{mg} / \mathrm{L}$ resulting 
Table 1 Chemical composition of groundwater

\begin{tabular}{|c|c|c|c|c|c|c|c|c|c|c|c|}
\hline S. no. & $\mathrm{pH}$ & $\begin{array}{l}\text { TDS } \\
(\mathrm{mg} / \mathrm{L})\end{array}$ & $\begin{array}{l}\mathrm{Ca}^{2+} \\
(\mathrm{mg} / \mathrm{L})\end{array}$ & $\begin{array}{l}\mathrm{Mg}^{2+} \\
(\mathrm{mg} / \mathrm{L})\end{array}$ & $\begin{array}{l}\mathrm{Na}^{+} \\
(\mathrm{mg} / \mathrm{L})\end{array}$ & $\begin{array}{l}\mathrm{K}^{+} \\
(\mathrm{mg} / \mathrm{L})\end{array}$ & $\begin{array}{l}\mathrm{HCO}_{3}^{-} \\
(\mathrm{mg} / \mathrm{L})\end{array}$ & $\begin{array}{l}\mathrm{Cl}^{-} \\
(\mathrm{mg} / \mathrm{L})\end{array}$ & $\begin{array}{l}\mathrm{SO}_{4}^{2-} \\
(\mathrm{mg} / \mathrm{L})\end{array}$ & $\begin{array}{l}\mathrm{NO}_{3}^{-} \\
(\mathrm{mg} / \mathrm{L})\end{array}$ & $\begin{array}{l}\mathrm{F}^{-} \\
(\mathrm{mg} / \mathrm{L})\end{array}$ \\
\hline 1 & 7.4 & 850 & 30 & 40 & 165 & 12 & 450 & 180 & 12 & 21 & 0.6 \\
\hline 2 & 7.5 & 950 & 35 & 55 & 173 & 12 & 430 & 220 & 56 & 29 & 0.7 \\
\hline 3 & 7.3 & 930 & 40 & 60 & 165 & 14 & 410 & 210 & 45 & 33 & 0.6 \\
\hline 4 & 8.2 & 990 & 45 & 55 & 185 & 14 & 460 & 195 & 56 & 46 & 0.8 \\
\hline 5 & 7.6 & 960 & 40 & 50 & 190 & 17 & 440 & 215 & 58 & 48 & 0.8 \\
\hline 6 & 7.9 & 980 & 50 & 40 & 205 & 13 & 450 & 200 & 55 & 51 & 0.9 \\
\hline 7 & 8.2 & 980 & 40 & 45 & 210 & 9 & 450 & 195 & 61 & 50 & 0.9 \\
\hline 8 & 7.9 & 960 & 35 & 40 & 220 & 8 & 440 & 225 & 43 & 49 & 0.8 \\
\hline 9 & 8.0 & 970 & 40 & 45 & 200 & 12 & 460 & 190 & 71 & 54 & 0.9 \\
\hline 10 & 7.6 & 1000 & 45 & 50 & 190 & 12 & 430 & 240 & 62 & 44 & 0.8 \\
\hline 11 & 7.8 & 1000 & 45 & 50 & 202 & 11 & 430 & 230 & 46 & 52 & 0.7 \\
\hline 12 & 7.9 & 1230 & 45 & 70 & 230 & 19 & 420 & 360 & 66 & 44 & 0.7 \\
\hline 13 & 7.3 & 1430 & 40 & 70 & 290 & 23 & 390 & 460 & 83 & 56 & 0.9 \\
\hline 14 & 7.5 & 1610 & 40 & 60 & 360 & 24 & 380 & 565 & 86 & 44 & 0.8 \\
\hline 15 & 7.2 & 1490 & 50 & 55 & 342 & 27 & 310 & 535 & 92 & 59 & 0.6 \\
\hline 16 & 7.4 & 1430 & 40 & 60 & 321 & 33 & 360 & 505 & 67 & 29 & 0.7 \\
\hline 17 & 7.9 & 1830 & 40 & 80 & 430 & 29 & 450 & 675 & 84 & 36 & 1.0 \\
\hline 18 & 8.2 & 1870 & 40 & 105 & 631 & 61 & 440 & 1020 & 136 & 82 & 1.3 \\
\hline 19 & 7.6 & 2150 & 70 & 85 & 482 & 34 & 350 & 810 & 110 & 63 & 0.9 \\
\hline 20 & 8.1 & 2930 & 40 & 115 & 720 & 59 & 480 & 1140 & 153 & 110 & 1.6 \\
\hline 21 & 8.2 & 3055 & 70 & 200 & 600 & 24 & 440 & 1325 & 84 & 63 & 1.4 \\
\hline 22 & 8.2 & 3000 & 60 & 165 & 676 & 83 & 520 & 1065 & 210 & 116 & 1.6 \\
\hline 23 & 8.2 & 2930 & 50 & 100 & 735 & 61 & 520 & 1165 & 185 & 86 & 1.5 \\
\hline 24 & 8.3 & 2600 & 50 & 120 & 625 & 39 & 540 & 990 & 190 & 62 & 1.6 \\
\hline 25 & 8.1 & 2080 & 40 & 85 & 480 & 58 & 450 & 750 & 90 & 66 & 1.0 \\
\hline 26 & 7.6 & 2665 & 40 & 115 & 610 & 92 & 340 & 1025 & 210 & 75 & 0.9 \\
\hline 27 & 8.2 & 3120 & 70 & 155 & 690 & 36 & 490 & 1300 & 120 & 54 & 1.2 \\
\hline 28 & 8.2 & 3190 & 75 & 195 & 733 & 62 & 550 & 1210 & 189 & 96 & 1.8 \\
\hline 29 & 8.2 & 3380 & 75 & 190 & 746 & 110 & 530 & 1315 & 232 & 123 & 1.7 \\
\hline 30 & 7.6 & 2670 & 40 & 110 & 670 & 39 & 350 & 1080 & 230 & 66 & 0.9 \\
\hline 31 & 7.4 & 2535 & 50 & 80 & 710 & 26 & 310 & 1110 & 94 & 43 & 0.8 \\
\hline 32 & 7.5 & 1950 & 50 & 70 & 475 & 18 & 360 & 780 & 53 & 35 & 0.8 \\
\hline 33 & 7.3 & 1560 & 50 & 60 & 360 & 17 & 350 & 590 & 45 & 47 & 0.7 \\
\hline 34 & 8.2 & 1760 & 50 & 80 & 380 & 23 & 480 & 600 & 49 & 33 & 1.0 \\
\hline 35 & 7.9 & 1820 & 50 & 70 & 429 & 39 & 400 & 640 & 56 & 26 & 1.0 \\
\hline 36 & 8.1 & 2015 & 40 & 85 & 480 & 36 & 410 & 765 & 109 & 49 & 1.1 \\
\hline 37 & 8.2 & 1755 & 60 & 55 & 417 & 19 & 430 & 670 & 59 & 49 & 1.0 \\
\hline 38 & 7.4 & 1690 & 50 & 60 & 400 & 10 & 320 & 640 & 53 & 43 & 0.8 \\
\hline 39 & 7.6 & 1500 & 55 & 60 & 350 & 14 & 370 & 565 & 12 & 46 & 0.7 \\
\hline 40 & 7.4 & 1235 & 35 & 75 & 260 & 28 & 310 & 425 & 68 & 36 & 0.6 \\
\hline 41 & 7.4 & 1230 & 55 & 50 & 265 & 26 & 310 & 380 & 96 & 43 & 0.6 \\
\hline 42 & 7.7 & 1430 & 65 & 80 & 324 & 19 & 390 & 525 & 54 & 46 & 0.9 \\
\hline 43 & 7.6 & 1560 & 75 & 70 & 310 & 11 & 410 & 520 & 110 & 21 & 0.8 \\
\hline 44 & 8.0 & 1690 & 75 & 80 & 394 & 23 & 440 & 630 & 61 & 36 & 1.0 \\
\hline 45 & 7.9 & 1625 & 30 & 55 & 390 & 16 & 380 & 610 & 56 & 51 & 0.9 \\
\hline 46 & 7.8 & 1365 & 60 & 80 & 296 & 18 & 420 & 460 & 49 & 33 & 0.8 \\
\hline 47 & 7.8 & 1300 & 40 & 75 & 295 & 32 & 480 & 370 & 110 & 38 & 0.8 \\
\hline
\end{tabular}


Table 1 continued

\begin{tabular}{|c|c|c|c|c|c|c|c|c|c|c|c|}
\hline S. no. & $\mathrm{pH}$ & $\begin{array}{l}\text { TDS } \\
(\mathrm{mg} / \mathrm{L})\end{array}$ & $\begin{array}{l}\mathrm{Ca}^{2+} \\
(\mathrm{mg} / \mathrm{L})\end{array}$ & $\begin{array}{l}\mathrm{Mg}^{2+} \\
(\mathrm{mg} / \mathrm{L})\end{array}$ & $\begin{array}{l}\mathrm{Na}^{+} \\
(\mathrm{mg} / \mathrm{L})\end{array}$ & $\begin{array}{l}\mathrm{K}^{+} \\
(\mathrm{mg} / \mathrm{L})\end{array}$ & $\begin{array}{l}\mathrm{HCO}_{3}{ }^{-} \\
(\mathrm{mg} / \mathrm{L})\end{array}$ & $\begin{array}{l}\mathrm{Cl}^{-} \\
(\mathrm{mg} / \mathrm{L})\end{array}$ & $\begin{array}{l}\mathrm{SO}_{4}{ }^{2-} \\
(\mathrm{mg} / \mathrm{L})\end{array}$ & $\begin{array}{l}\mathrm{NO}_{3}^{-} \\
(\mathrm{mg} / \mathrm{L})\end{array}$ & $\begin{array}{l}\mathrm{F}^{-} \\
(\mathrm{mg} / \mathrm{L})\end{array}$ \\
\hline 48 & 7.4 & 1370 & 30 & 70 & 310 & 16 & 390 & 500 & 33 & 40 & 0.8 \\
\hline 49 & 8.2 & 1240 & 60 & 75 & 285 & 10 & 430 & 365 & 49 & 51 & 1.4 \\
\hline 50 & 8.2 & 1430 & 30 & 50 & 260 & 19 & 550 & 425 & 24 & 19 & 1.8 \\
\hline Mean & 7.81 & 1745.80 & 48.60 & 80.90 & 399.12 & 29.34 & 429.00 & 623.30 & 88.40 & 51.84 & 0.98 \\
\hline SD & 0.34 & 716.67 & 12.90 & 39.52 & 182.17 & 22.37 & 64.17 & 346.30 & 56.30 & 22.89 & 0.33 \\
\hline $\mathrm{CV}$ & 4.35 & 41.05 & 26.54 & 48.85 & 45.64 & 76.24 & 14.96 & 55.56 & 63.69 & 44.16 & 33.67 \\
\hline
\end{tabular}

$S D$ standard deviation, $C V$ coefficient of variation

in fluorosis (USPHS 1987). Therefore, the lowest and highest desirable limits of $\mathrm{F}^{-}$are considered as 0.60 and $1.20 \mathrm{mg} / \mathrm{L}$, respectively, in the present study area.

From Table 1, it is noted that the concentration of $\mathrm{F}^{-}$ $(0.60-1.80 \mathrm{mg} / \mathrm{L})$ is not uniform in the study area. For example, the $\mathrm{F}^{-}$content varies from 0.60 to $0.90 \mathrm{mg} / \mathrm{L}$ in $64 \%$ of the groundwater samples ( 1 to $16,19,26,30-33$, $38-43$ and $45-48$ ); from 0.90 to $1.20 \mathrm{mg} / \mathrm{L}$ in $16 \%$ of the groundwater samples $(17,25,27,34-37$ and 44$)$; from 1.20 to $1.50 \mathrm{mg} / \mathrm{L}$ in $8 \%$ of the groundwater samples $(18,21$, 23 and 49); and from 1.50 to $1.80 \mathrm{mg} / \mathrm{L}$ in the remaining $12 \%$ of the groundwater samples $(20,22,24,28,29$ and 50). It is also observed that the $\mathrm{pH}, \mathrm{Mg}^{2+}, \mathrm{Na}^{+}, \mathrm{K}^{+}$, $\mathrm{HCO}_{3}{ }^{-}, \mathrm{Cl}^{-}, \mathrm{SO}_{4}{ }^{2-}$ and $\mathrm{NO}_{3}{ }^{-}$follow a similar trend of $\mathrm{F}^{-}$ (Table 2).

For assessing the factors that control the $\mathrm{F}^{-}$content in the groundwater, understanding the influences of climate, slope, soil cover, lithology, anthropogenic activity and marine source on spatial distribution of $\mathrm{F}^{-}$is very essential. Figure 6 shows the spatial distribution of $\mathrm{F}^{-}$content in the study area. It indicates a progressive increase of $\mathrm{F}^{-}$ from 0.60 to $0.90,0.90-1.20,1.20-1.50$ and $1.50-1.80 \mathrm{mg} /$ $\mathrm{L}$ towards the southern part from the northern part. Significantly, the higher concentration of $\mathrm{F}^{-}(1.20-1.80 \mathrm{mg} / \mathrm{L})$ is observed from the central and southern parts.

Dry climate is known to increase both the solubility and the rate of dissolution of soil salts and/or rock minerals. In addition to this, the climate also increases the rate of evaporation. The slope of the study area is gentle, which leads to slow movement of water. It causes a longer contact time of water with the aquifer material, thereby increasing the solubility of ions. The sand aquifer occurs mainly in the northern part, which reflects the higher rate of water circulation due to its high hydraulic conductivity. Thus, it supports a lesser solubility of ions. The increase of clay content from the northern to the southern part tends to slow water movement, because of its low hydraulic conductivity. This not only causes the increase of ions solubility, but also supports anion exchange. The occurrence of the Charnockite Group of rocks in the southern part (especially in and around Ongole) shows low weathered and fractured portions, thereby causing a low hydraulic conductivity. In addition to this, the rocks contain the $\mathrm{F}^{-}$-bearing minerals (apatite, hornblende and biotite). The influences of salt pans and aqua-cultural activity on the groundwater system are dominant in the central part, while the impact of domestic wastes, leakage of septic tanks and agro-chemicals on the groundwater body is predominant in the remaining part. Thus, the soil-rock-water interaction appears as a prime geogenic factor for a source of $\mathrm{F}^{-}$and the influences of anthropogenic activities as a supplementary factor for further increase of $\mathrm{F}^{-}$in the groundwater system. This hypothesis is explained below, using binary diagrams, for understanding the factors that control the $\mathrm{F}^{-}$ content in the groundwater in the study area.

The $\mathrm{F}^{-}$is plotted against $\mathrm{pH}, \mathrm{HCO}_{3}{ }^{-}$and $\mathrm{Ca}^{2+}$ (Figs. 7, 8 , 9). The $\mathrm{F}^{-}$shows a significant positive correlation ( $r)$ with $\mathrm{pH}(r=0.75)$ and $\mathrm{HCO}_{3}{ }^{-}(r=0.64)$, while it has a poor positive relation with $\mathrm{Ca}^{2+}(r=0.32)$. Further, the $\mathrm{pH}$ has a good positive correlation with $\mathrm{HCO}_{3}{ }^{-}(r=0.78$; Fig. 10), as the infiltrated water reacts with soil $\mathrm{CO}_{2}$, which forms $\mathrm{H}_{2} \mathrm{O}_{3}$, resulting $\mathrm{HCO}_{3}{ }^{-}$and thereby causing a $\mathrm{pH}$ (Berner and Berner 1987). On the other hand, the incongruent dissolution of rock weathering causes a release of $\mathrm{HCO}_{3}{ }^{-}$(Drever 1997). This indicates a prevailing condition of alkalinity (caused by $\mathrm{HCO}_{3}{ }^{-}$only here) in the groundwater, which promotes a mineral dissolution (Stumm and Morgan 1996). Further, an easy accessibility of circulating water caused by rainwater and/or intensive and long-term irrigation practices in the soil and/or weathered zone stimulates the alkalinity more effectively (Wodeyar and Sreenivasan 1996; Subba Rao 2003, 2011; Madhnure et al. 2007). Thus, the alkaline water activates the leaching of $\mathrm{F}^{-}$-bearing minerals (apatite, hornblende and biotite) present in the host rocks. As a result, the chemical relations obviously indicate a greater affinity of $\mathrm{F}^{-}$with $\mathrm{HCO}_{3}{ }^{-}$rather than with $\mathrm{Ca}^{2+}$. Further, it appears that the residence time of water in the aquifer zone could be high, because of the gentle slope and the occurrence of clays in the soil zone as well as in the sub-surface at 


\begin{tabular}{|c|c|}
\hline 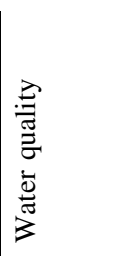 & 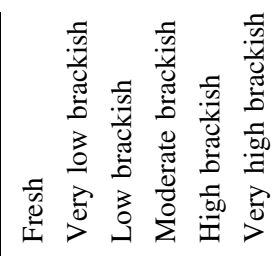 \\
\hline 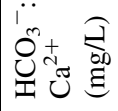 & 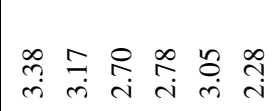 \\
\hline 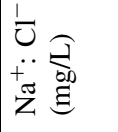 & 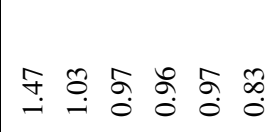 \\
\hline is & 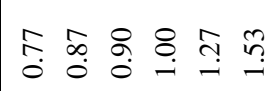 \\
\hline & 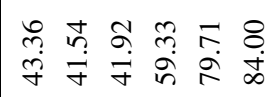 \\
\hline & 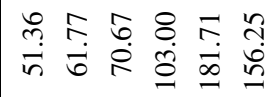 \\
\hline 它 & 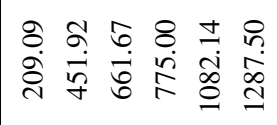 \\
\hline & 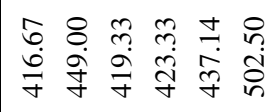 \\
\hline 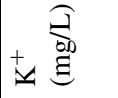 & 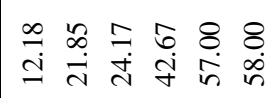 \\
\hline 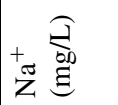 & 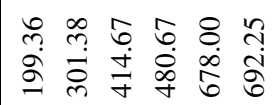 \\
\hline 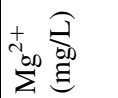 & 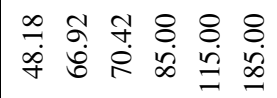 \\
\hline 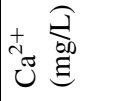 & 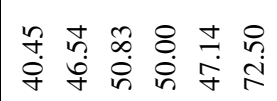 \\
\hline 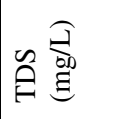 & 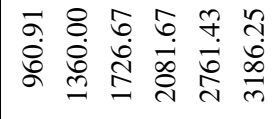 \\
\hline-7 & 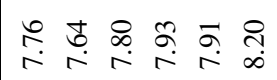 \\
\hline 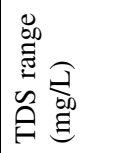 & 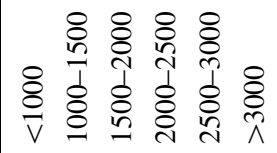 \\
\hline 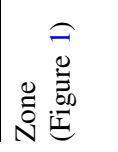 & \\
\hline
\end{tabular}

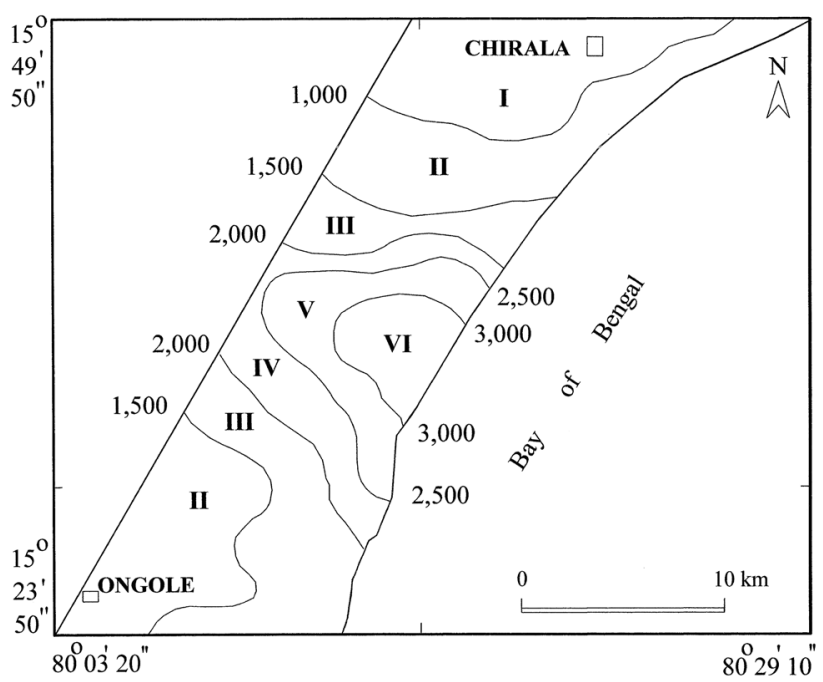

Fig. 5 Spatial distribution of TDS (mg/L) in the study area

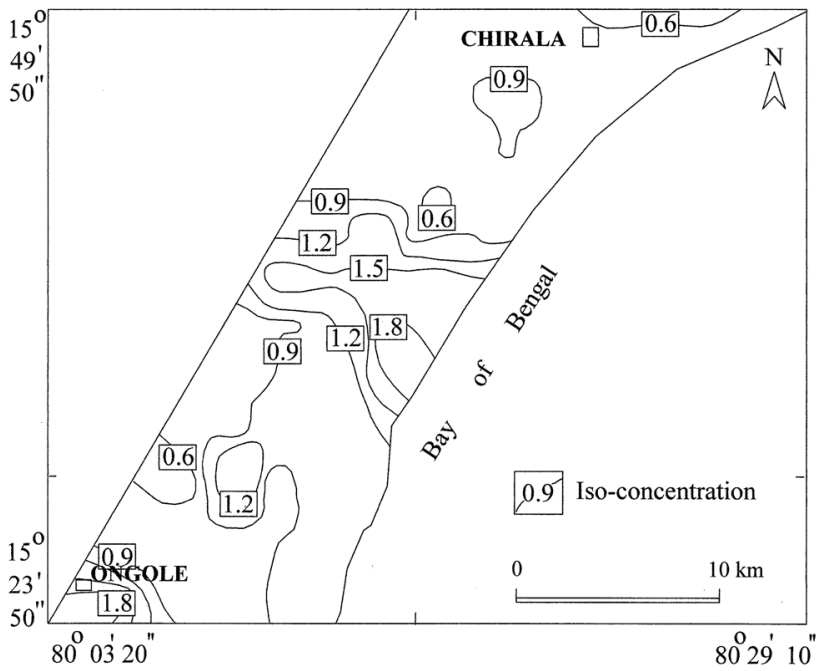

Fig. 6 Spatial distribution of $\mathrm{F}^{-}$content $(\mathrm{mg} / \mathrm{L})$ in the study area

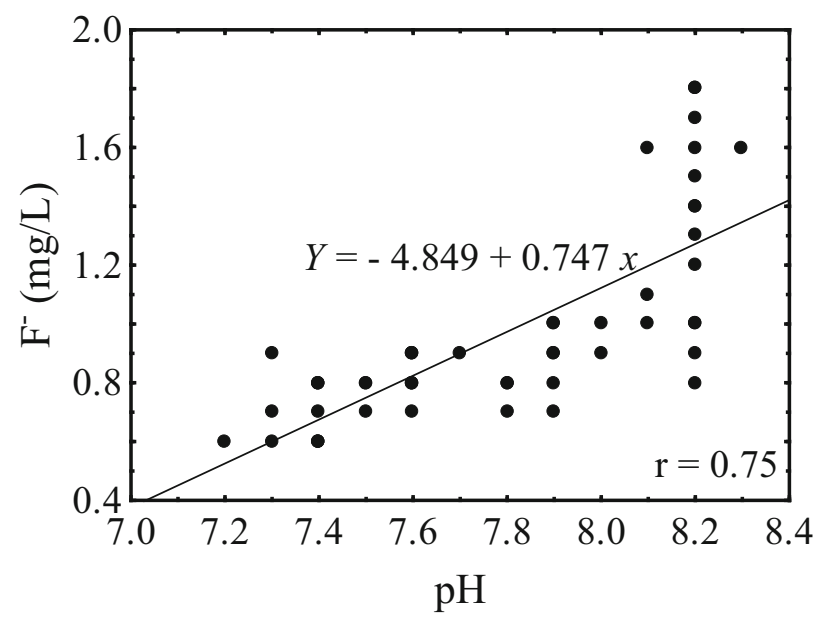

Fig. 7 Correlation between $\mathrm{pH}$ and $\mathrm{F}^{-}$ 


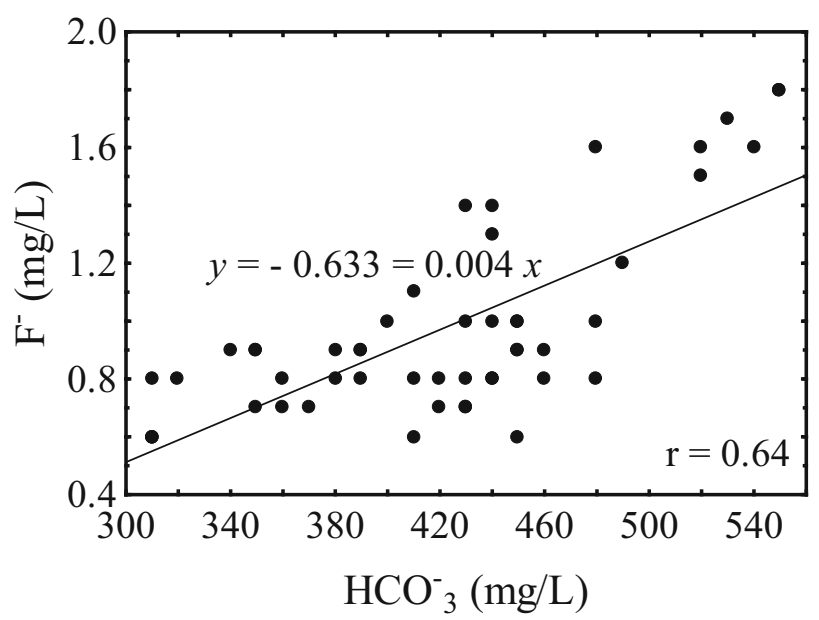

Fig. 8 Correlation between $\mathrm{HCO}_{3}{ }^{-}$and $\mathrm{F}^{-}$

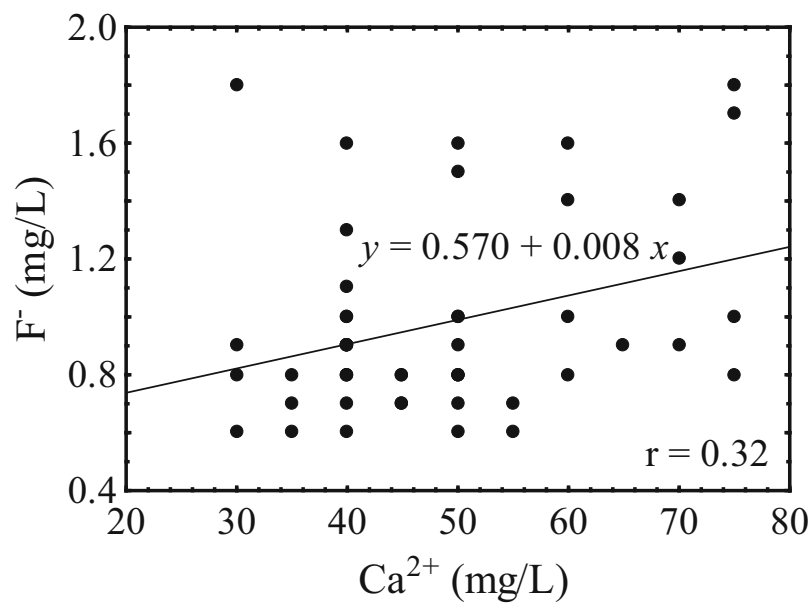

Fig. 9 Correlation between $\mathrm{Ca}^{2+}$ and $\mathrm{F}^{-}$

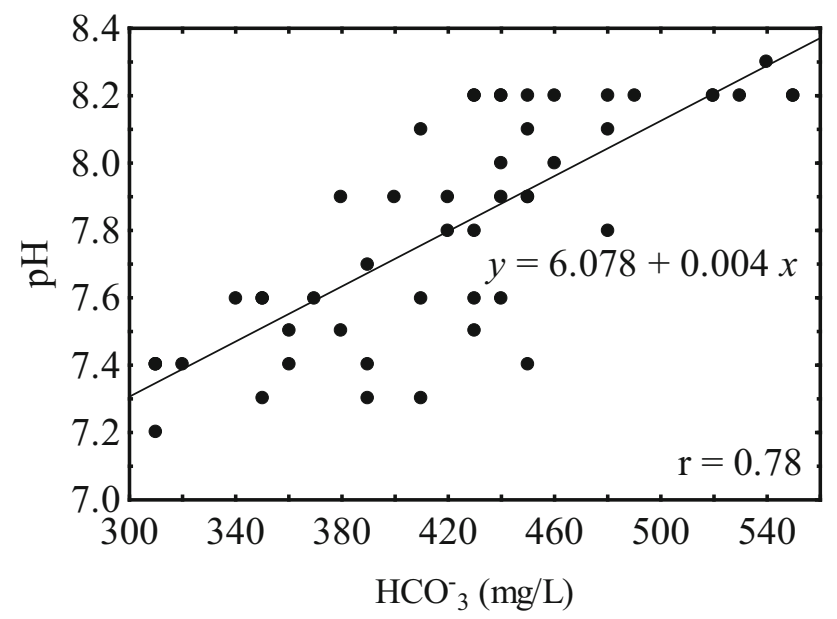

Fig. 10 Correlation between $\mathrm{HCO}_{3}{ }^{-}$and $\mathrm{pH}$ different depths in the study area. This facilities not only active solubility and dissolution of $\mathrm{F}^{-}$-bearing minerals, but also activate anion exchange between $\mathrm{F}^{-}$and $\mathrm{OH}^{-}$ (Robinson and Edington 1946; Hem 1991), which favours the increase of $\mathrm{F}^{-}$content in the groundwater. Therefore, the $\mathrm{F}^{-}$shows a good correlation with $\mathrm{pH}$ and $\mathrm{HCO}_{3}{ }^{-}$ (Figs. 7, 8) as well as a poor relation with $\mathrm{Ca}^{2+}$ (Fig. 9). Similar correlation trends are also observed from other regions, which are discussed in the review literature.

Influences of saline water, chemical activity (ion exchange) and climate (evaporation) also play an important role for increasing $\mathrm{F}^{-}$content in the groundwater. An insignificant correlation between $\mathrm{Na}^{+}$and $\mathrm{Ca}^{2+}(r=0.38$; Fig. 11) is observed from the groundwater due to increase of $\mathrm{Na}^{+}$caused by ion exchange between $\mathrm{Na}^{+}$and $\mathrm{Ca}^{2+}$, and decrease of $\mathrm{Ca}^{2+}$ (Gao et al. 2007, 2013; Singaraja et al. 2013; Subba Rao et al. 2014a, b; Surya Rao et al. 2015). Impacts of saline water (used for salt pans and aquacultural activities), domestic wastes, leakage of septic tanks and clays are responsible for additional source of $\mathrm{Na}^{+}$ (Todd 1980; Hem 1991; Subba Rao 2014; Subba Rao et al. $2014 a, b)$. On the other hand, the solubility of $\mathrm{F}^{-}$is low and its dissolution rate is slow (Nordstrom and Jenne 1977). But the solubility of $\mathrm{F}^{-}$increases with the increase of $\mathrm{Na}^{+}$in the groundwater (Apambire et al. 1997; Gao et al. 2007, 2013; Singaraja et al. 2013; Surya Rao et al. 2015). Further, the dry climate increases the rate of solubility and dissolution of minerals present in the host rocks (Hem 1991). It also increases the rate of evaporation, which rises the $\mathrm{pH}$ levels due to loss of $\mathrm{CO}_{2}$ along with water (Handa 1975). This causes a precipitation of $\mathrm{CaCO}_{3}$. The occurrence of kankar in the soil zone further supports this hypothesis so that the groundwater in the study area shows an oversaturation with respect to solid phase of $\mathrm{CaCO}_{3}$ (Table 3). This also causes in reduction in $\mathrm{Ca}^{2+}$

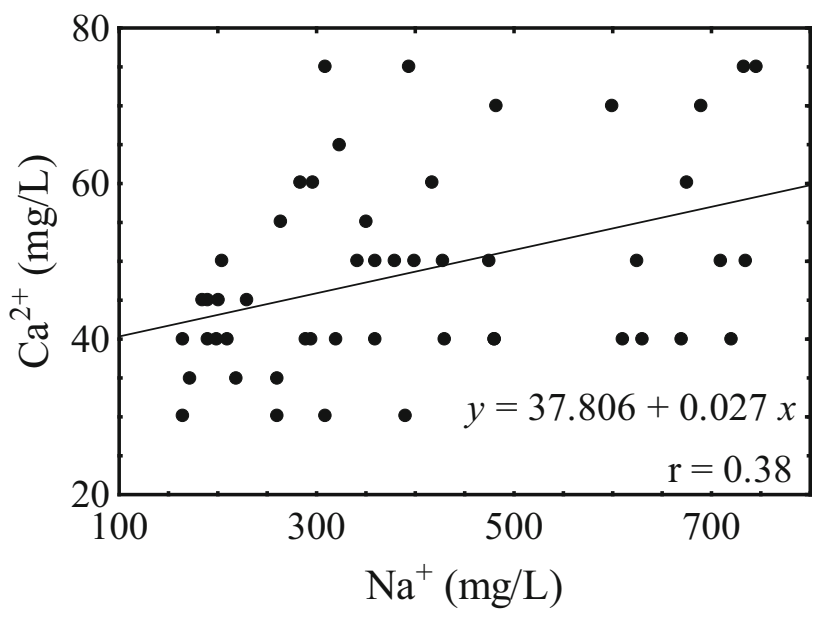

Fig. 11 Correlation between $\mathrm{Na}^{+}$and $\mathrm{Ca}^{2+}$ 
Table 3 Saturation index

\begin{tabular}{lcl}
\hline Particulars & Saturation index & Remarks \\
\hline $\mathrm{CaCO}_{3}$ & 3.12 & Precipitation \\
$\mathrm{CaF}_{2}$ & -2.13 & Dissolution \\
\hline
\end{tabular}

content. As a result, it favours a higher dissolution of $\mathrm{CaF}_{2}$ from the source material to compensate for requirement of $\mathrm{Ca}^{2+}$ ions in the chemical equlibria (Freeze and Cherry 1979). Thus, it shows an under saturation with respect to $\mathrm{CaF}_{2}$, causing a higher $\mathrm{F}^{-}$content in the groundwater and thereby the $\mathrm{Na}^{+}$shows a good positive correlation with $\mathrm{F}^{-}$ ( $r=0.69$; Fig. 12) and a poor positive relation with $\mathrm{Ca}^{2+}$ ( $r=0.38$; Fig. 11), as also discussed earlier in the review literature from other regions. Further, the poor relation between $\mathrm{Na}^{+}$and $\mathrm{Ca}^{2+}$ is a result of the concurrent increase or decrease in the cations, depending upon the dissolution, precipitation, concentration effects and ion exchange (Admas et al. 2001).

The increase of $\mathrm{Na}^{+}: \mathrm{Cl}^{-}$ratio from 0.83 to 1.47 (Table 2) indicates modification of $\mathrm{NaCO}_{3}$ water $\left(\mathrm{Na}^{+}: \mathrm{Cl}^{-}\right.$ $>1.0)$ by dissolution or mixing of $\mathrm{NaCl}\left(\mathrm{Na}^{+}: \mathrm{Cl}^{-}<1.0\right.$; Dhiman and Keshari 2006; Gao et al. 2007, 2013), while the ratio of $\mathrm{HCO}_{3}{ }^{-}: \mathrm{Ca}^{2+}$ increases from 2.28 to 3.38 , which signifies an increase of $\mathrm{HCO}_{3}{ }^{-}$(Saxena and Ahmed 2003). The concentration of $\mathrm{F}^{-}(0.77-1.53 \mathrm{mg} / \mathrm{L})$ also follows a similar trend of $\mathrm{Na}^{+}: \mathrm{Cl}^{-}$and $\mathrm{HCO}_{3}{ }^{-}: \mathrm{Ca}^{2+}$ ratios. These infer that the $\mathrm{Na}^{+}$and $\mathrm{HCO}_{3}{ }^{-}$favour the chemical condition for dissolution of $\mathrm{F}^{-}$and, therefore, a good positive correlation of $\mathrm{F}^{-}$with $\mathrm{HCO}_{3}{ }^{-}(r=0.64)$ and $\mathrm{Na}^{+}(r=0.69)$ is observed from the study area (Figs. 8, 12), as also reported similar observations (discussed in review literature) from other regions. This is also supported by the hydrogeochemical facies.

A positive correlation of $\mathrm{F}^{-}$with $\mathrm{K}^{+}(r=0.59), \mathrm{SO}_{4}{ }^{2-}$ $(r=0.56)$ and $\mathrm{NO}_{3}{ }^{-}(r=0.64)$ is observed from the study

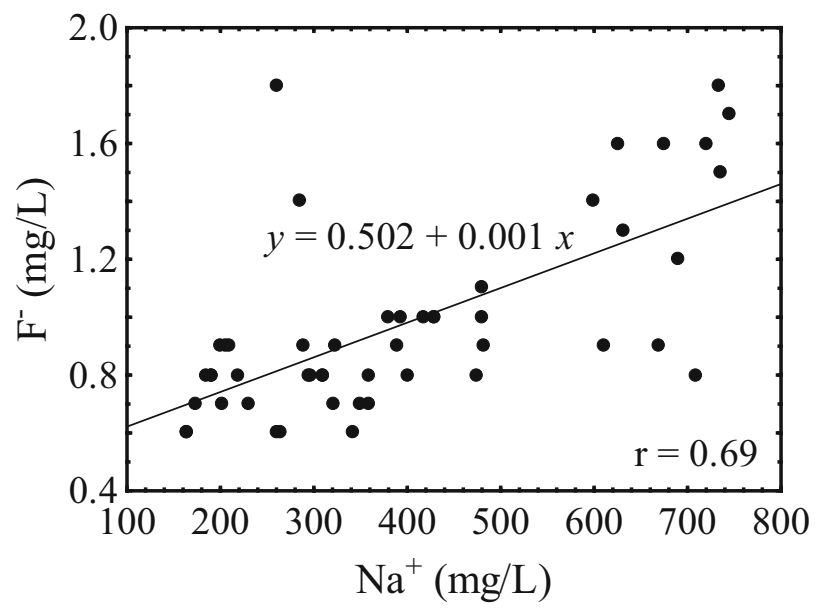

Fig. 12 Correlation between $\mathrm{Na}^{-}$and $\mathrm{F}^{-}$ area (Figs. 13, 14, 15), as also discussed similar results from other regions (in review literature). This indicates the influences of uncontrolled usage of agro-chemicals (nitrogen, phosphate and potash fertilisers) and soil amendments (gypsum) for higher crop yields, because the nitrogen variety promotes over-grass shoot growth, phosphate type supports strong root growth, potash variety helps gross withstand stress, drought or disease and gypsum aids to alter the physical or chemical properties of the soils (Todd 1980; Fekri and Kasmaei 2013; Subba Rao 2014). Therefore, these chemicals are responsible for the concentrations of $\mathrm{F}^{-}, \mathrm{K}^{+}, \mathrm{SO}_{4}{ }^{2-}$ and $\mathrm{NO}_{3}{ }^{-}$in the groundwater. In addition to this, domestic wastes and leakage of septic tanks contribute $\mathrm{K}^{+}$and $\mathrm{NO}_{3}{ }^{-}$to the groundwater system (Bhosle et al. 2001; Ayoob and Gupta 2006; Subba Rao 2014; Subba Rao et al. 2014a, b). Thus, the anthropogenic activities appear as a supplementary source of $\mathrm{F}^{-}$to its further elevation in the groundwater.

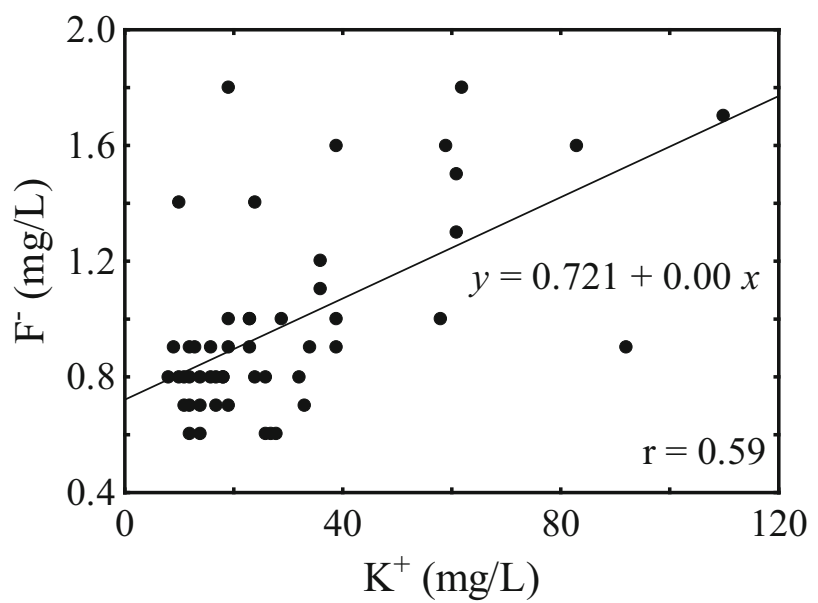

Fig. 13 Correlation between $\mathrm{K}^{+}$and $\mathrm{F}^{-}$

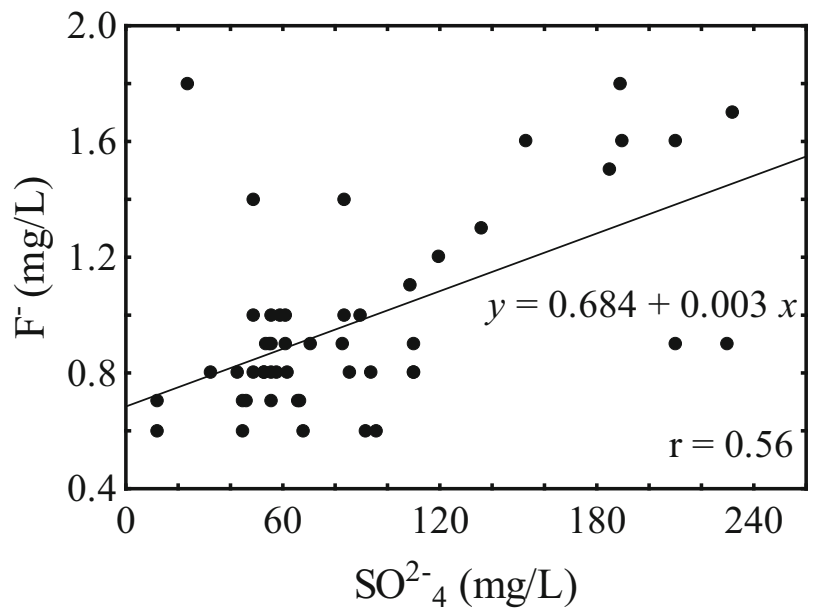

Fig. 14 Correlation between $\mathrm{SO}_{4}{ }^{2-}$ and $\mathrm{F}^{-}$ 


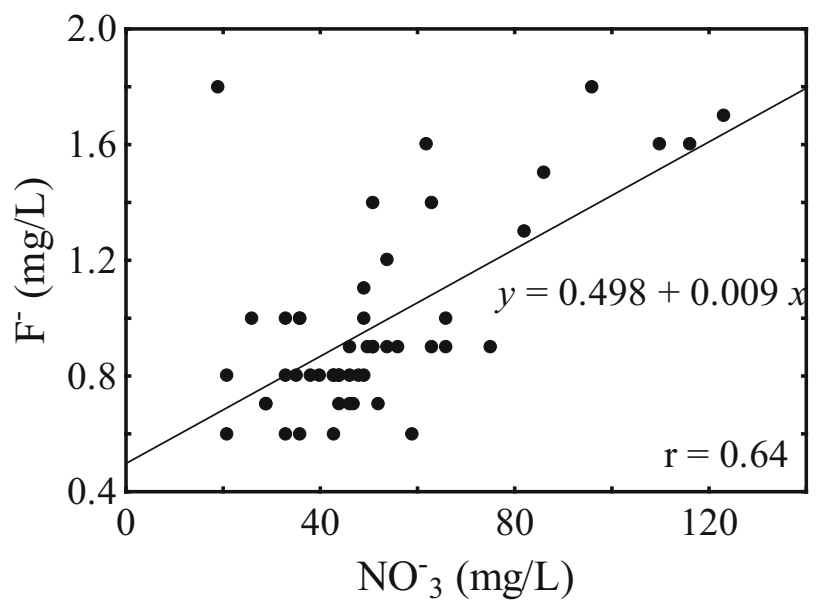

Fig. 15 Correlation between $\mathrm{NO}_{3}{ }^{-}$and $\mathrm{F}^{-}$

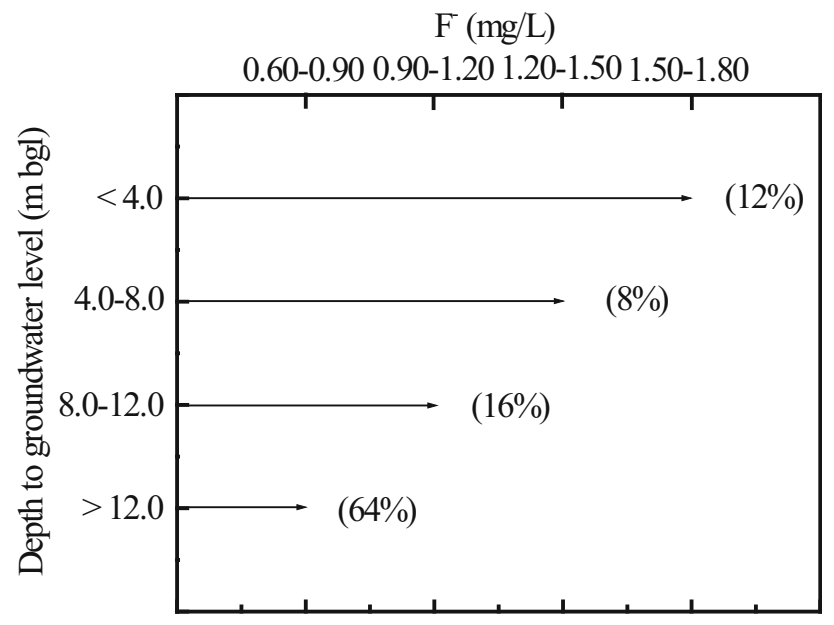

Fig. 16 Fluoride content with depth to groundwater level. Value in bracket denotes percentage of wells

Figure 16 shows that the concentration of $\mathrm{F}^{-}$increases with the decrease of the depth. It suggests that the factors that control the $\mathrm{F}^{-}$content in the groundwater are prevalent in the shallow depth rather than those in the deeper level. It is a result of higher rate of solubility, dissolution and leaching of salts present in soil and/or weathered zone, and ion exchange and evaporation in the shallow depth. This is also supported by the above discussion explained for understanding the causative factors that control the $\mathrm{F}^{-}$ content in the groundwater.

\section{Remedial measures}

(a) The study area receives $94 \%(846 \mathrm{~mm})$ of the total rainfall during monsoon. It can be possible to reduce the $\mathrm{F}^{-}$content in the groundwater, if a number of rainwater harvesting structures are constructed, as reported in other regions (Narasimha and Pradeep 1997; Bhagavan and Raghu 2005). This is a simple low-cost alternative to the existing high-cost approaches (Nalgonda technique, activated alumina, red mud, montmorillonite, magnesia, etc.).

(b) Calcium food is essential to control the $\mathrm{F}^{-}$content in the human body.

(c) Application of $\mathrm{CaSO}_{4}$ and $\mathrm{CaCl}$ can also reduce the $\mathrm{F}^{-}$content in the groundwater (Fekri and Kasmaei 2013).

(d) Public awareness on causes of high concentration $\mathrm{F}^{-}$ in drinking water and its health implications is necessary for success of groundwater quality management measures.

(e) The study helps the planning authorities to mitigate the $\mathrm{F}^{-}$content in the drinking water.

\section{Conclusions}

Fluoride varies from 0.60 to $1.80 \mathrm{mg} / \mathrm{L}$ in the coastal region, which exceeds the threshold limit of $1.20 \mathrm{mg} / \mathrm{L}$ in $20 \%$ of the total groundwater samples. The occurrence of $\mathrm{F}^{-}$-bearing minerals in the country rocks are the main geogenic source of $\mathrm{F}^{-}$in the groundwater. Alkalinity $(\mathrm{pH}$ and $\mathrm{HCO}_{3}{ }^{-}$) plays a significant role in dissolution and leaching of $\mathrm{F}^{-}$. As a result, a positive correlation of $\mathrm{F}^{-}$ with $\mathrm{pH}$ and $\mathrm{HCO}_{3}{ }^{-}$is observed. The clays lead to a longer contact of water with aquifer material for active solubility and dissolution of $\mathrm{F}^{-}$-bearing minerals, and are also responsible for anion exchange between $\mathrm{F}^{-}$and $\mathrm{OH}^{-}$. The influences of saline water, ion exchange between $\mathrm{Na}^{+}$and $\mathrm{Ca}^{2+}$, and the precipitation of $\mathrm{CaCO}_{3}$ due to evaporation reduce the $\mathrm{Ca}^{2+}$ content, which favour to dissolve $\mathrm{CaF}_{2}$ to maintain the chemical equilibria. Thus, there is a positive correlation between $\mathrm{Na}^{+}$and $\mathrm{F}^{-}$. Anthropogenic activities act as supplementary factor for further elevation of $\mathrm{F}^{-}$in the groundwater. This is supported by positive correlation of $\mathrm{F}^{-}$with $\mathrm{K}^{+}, \mathrm{SO}_{4}{ }^{2-}$ and $\mathrm{NO}_{3}{ }^{-}$. These factors are dominant in shallow depth so that the groundwater shows higher content of $\mathrm{F}^{-}$in the shallow depth than that in the deeper depth. Hydrogeochemical facies also support this hypothesis. Appropriate management measures are suggested to reduce the $\mathrm{F}^{-}$in the groundwater.

Acknowledgments The author (NSR) acknowledges the financial support (DST/WAR-W/WSI/08/2010) received from the Department of Science and Technology, New Delhi to carry out this work. Prof. P. Bhanumurthy, Co-Principal Investigator and Mr. G. Vidyasagar, Research Scholar is thanked for their help during the work. The author (NSR) thanks anonymous reviewers and editor of the journal for their critical and constructive suggestions in bringing the manuscript in the present form. 
Open Access This article is distributed under the terms of the Creative Commons Attribution 4.0 International License (http:// creativecommons.org/licenses/by/4.0/), which permits unrestricted use, distribution, and reproduction in any medium, provided you give appropriate credit to the original author(s) and the source, provide a link to the Creative Commons license, and indicate if changes were made.

\section{References}

Admas S, Tredoux G, Harris C, Titus R, Pietersen K (2001) Hydrochemical characteristics of aquifers near Sutherland in the Western Karoo, South Africa. J Hydrol 241:91-103

Agrawal V, Vaish AK, Vaish P (1997) Groundwater quality-focus on fluoride and fluorosis in Rajasthan. Curr Sci 73:743-746

Ahmed AA (2014) Fluoride in Quaternary groundwater aquifer, Nile Valley, Luxor, Egypt. Arab J Geosci 7:3069-3083

Apambire WB, Boyle DR, Michel FA (1997) Geochemistry, genesis and health implications of fluoriferous groundwaters in the upper regions of Ghanna. Environ Geol 33:13-24

APHA (1999) Standard methods for the examination of water and wastewater. American Public Health Association, Washington, DC

Ayoob S, Gupta AK (2006) Fluoride in drinking water: a review on the status and stress effects. Crit Rev Environ Sci Tech $36: 433-487$

Berner EK, Berner RA (1987) The global water cycle, geochemistry and environment. Prentice-Hall, New Jersey

Bhagavan SVBK, Raghu V (2005) Utility of check dams in dilution of fluoride concentration in groundwater and the resultant analysis of blood serum and urine of villagers, Anantapur District, Andhra Pradesh, India. Environ Geochem Health 27:97-108

Bhosle AB, Narkhede RK, Rao Balaji, Patil PM (2001) Studies on the fluoride content of Godavari river water at Nanded. Econ Environ Conserv 7:341-344

CGWB (2002) Basic data reports of exploratory wells drilled in Prakasam District. Central Ground Water Board, Southern Region, Hyderabad

CGWB (2013) Groundwater brochure, Prakasam district, Andhra Pradesh (AAP-2012-13). Central Ground Water Board, Southern Region, Hyderabad

Chakraborti D, Chanda CR, Samanta G, Chowdhury UK, Mukherjel SC, Pal AB, Sharma B, Mahanta KJ, Ahmed HA, Sing B (2000) Fluorosis in Assam, India. Curr Sci 78:1421-1423

Chatterjee MK, Mohabey NK (1998) Potential fluorosis problems around Chandidongri, Madhya Pradesh, India. Environ Geochem Health 20:1-4

Chidambaram S, Bala Krishna Prasad M, Manivannan R, Karmegam U, Singaraja C, Anandhan P, Prasanna MV, Manikandan S (2013) Environmental hydrogeochemistry and genesis of fluoride in groundwaters of Dindigul District, Tamilnadu (India). Environ Earth Sci 68:333-342

Das B, Talukdar J, Sarma S, Gohain B, Dutta RK, Das HB, Das SC (2003) Fluoride and other inorganic constituents in groundwater of Guwahati, Assam, India. Curr Sci 85:657-661

Datta PS, Deb DL, Tyagi SK (1996) Stable isotope $\left({ }^{18} \mathrm{O}\right)$ investigations on the processes controlling fluoride contamination of groundwater. J Contam Hydrol 24:85-96

Deepu TR, Shaji E (2011) Fluoride contamination in groundwater resources of Chittur block, Palghat district, Kerala, India-a health risk. In: Disaster, Risk and vulnerability conference 2011. School of Environmental Sciences, Mahatma Gandhi University,
India in association with the Applied Geoinformatics for Society and Environment, Germany, 12-14 March 2011

Deutsch WJ (1997) Groundwater geochemistry fundamentals and application to contamination. Lewis Publishers, Boca Raton

Dhiman SD, Keshari AK (2006) GIS assisted inverse geochemical modeling for plausible phase transfers in aquifers. Environ Geol 50:1211-1219

Drever JI (1997) The geochemistry of natural waters, 3rd edn. Prentice Hall, Englewood 436 p

Eenadu (2013) Relief to fluoride-affected areas in budget 2013 (daily news paper in Telugu), p 6

Fekri M, Kasmaei LS (2013) Fluoride pollution in soils and waters of Koohbanan region, southeastern Iran. Arab J Geosci 6:157-161

Fetter CW (1990) Applied hydrogeology. CBS Publishers \& Distributors, New Delhi 592 p

Freeze RA, Cherry JA (1979) Groundwater. Prentice-Hall, New Jersey, p 603

Gao X, Wang Y, Li Y, Guo Q (2007) Enrichment of fluoride in groundwater under the impact of saline water intrusion $t$ the salt lake area of Yuncheng basin, Northern China. Environ Geol 53:795-803

Gao XB, Zhang FC, Wang C, Wang YX (2013) Coexistence of high fluoride fresh and saline groundwaters in the Yuncheng Basin, northern China. Proc Earth Planet Sci 7:280-283

Gupta MK, Singh V, Rajwanshi P, Agarwal M, Rai K, Srivastava S, Shrivastav R, Dass S (1999) Groundwater quality assessment of Tehsil Kheragarh Agra (India) with special reference to fluoride. Environ Monit Assess 59:272-285

Gupta SK, Deshpande RD, Agarwal M, Raval BR (2005) Origin of high fluoride in groundwater in the North Gujarat-Cambay region India. Hydrogeol J 13:596-605

Handa BK (1975) Geochemistry and genesis of fluoride-containing groundwater in India. Ground Water 13:275-281

Hem JD (1991) Study and interpretation of the chemical characteristics of natural water. In: United States Geological Survey professional paper 2254, Scientific Publisher, Jodhpur

ISI (2012) Indian standard drinking water-specification. Indian Standard Institute, IS: 10500

Jacks G, Rajagopalan K, Alveteg T, Johnsson M (1993) Genesis of high-F groundwaters, Southern India. Appl Geochem (supplementary) 2:241-244

Jacks G, Bhattacharya P, Chaudhary V, Singh KP (2005) Controls on the genesis of some high-fluoride groundwaters in India. Appl Geochem 20:221-228

Jha LB, Jha M (1982) Fluoride pollution in India. Int J Environ Stud 19:225-230

Kundu MC, Mandal B (2009a) Agricultural activities influence nitrate and fluoride contamination in drinking groundwater of an intensively cultivated district in India. Water Air Soil Pollut 198:243-252

Kundu MC, Mandal B (2009b) Assessment of potential hazards of fluoride contamination in drinking groundwater of an intensively cultivated district in West Bengal, India. Environ Monit Assess 152:97-103

Kundu N, Panigrahi MK, Tripathy S, Munshi S, Powell MA, Hart BR (2001) Geochemical appraisal fluoride contamination of groundwater in Nayagarh District of Orissa, India. Ind J Environm Health 41:451-460

Madhavan N, Subramanian V (2002) Fluoride in fractioned soil samples of Ajmer District, Rajasthan. J Environ Monit $4: 821-822$

Madhnure P, Sirsikar DY, Tiwari AN, Ranjan B, Malpe DB (2007) Occurrence of fluoride in the groundwaters of Pandharkawada area, Yavatmal District, Maharashtra, India. Curr Sci 92:675-679 
Manikandan S, Chidambaram S, Ramanathan AL, Prasanna MV, Karmegam U, Singaraja C, Paramaguru P, Jainab I (2014) A study on the high fluoride concentration in the magnesium-rich waters of hard rock aquifer in Krishnagiri district, Tamilnadu, India. Arab J Geosci 7:273-285

Misra AK, Mishra A (2006) Study of quaternary aquifers in Ganga Plain, India: focus on groundwater salinity, fluoride and fluorosis. J Hazard Mater 144:438-448

Muralidharan D, Nair A, Satyanarayana U (2002) Fluoride in shallow aquifers in Rajgarh Teshil of Churu District, Rajashtan — an arid environment. Curr Sci 83:699-702

Narasimha RT, Pradeep R (1997) Hydrogeological conditions and optimum well discharges in granitic terrain in parts of Nalgonda District, Andhra Pradesh, India. J Geol Soci India 49:61-74

Nordstrom DK, Jenne EA (1977) Fluoride solubility in selected geothermal waters. Geochim Cosmochim Acta 41:175-188

Raju JN, Dey S, Das K (2009) Fluoride contamination in groundwater of Sonbhadra District, Uttar Pradesh, India. Curr Sci 96:979-985

Ramachandran M, Chidambaram S, Ulaganthan K, Paluchamy A, Sivaji M, Hameed S (2012) Mapping of fluoride ions in groundwater of Dindigul district, Tamilnadu, India-using GIS technique. Arab J Geosci 5:433-439

Ramamohana Rao NV, Suryaprakasa Rao K, Schuiling RD (1993) Fluorine distribution in waters of Nalgonda District, Andhra Pradesh, India. Environ Geol 21:84-89

Ramesam V, Rajagopalan K (1985) Fluoride ingestion into the natural water of hard rock areas, Peninsular India. J Geol Soci India 26:125-132

Rao PN, Rao AD, Bhargav JS, Siva Sankar K, Sudharshan G (2014) Regional appraisal of the fluoride occurrence in groundwaters of Andhra Pradesh. J Geol Soc India 84:483-493

Ray D, Rao RP, Bhoi AV, Biswas AK, Ganguly AK, Sanyal PI (2000) Physico-chemical quality of drinking water in Rohtas District of Bihar. Environ Monit Assess 61:387-398

Reddy DV, Nagabhushanam P, Sukhija BS, Reddy AGS, Smedley PL (2010) Fluoride dynamics in the granitic aquifer of the Wailapally watershed, Nalgonda District, India. Chem Geol 269:278-289

Robinson WD, Edington G (1946) Fluorine in soils. Soil Sci 61:341-353

Sahu NK, Karim MA (1989) Fluoride incidence in groundwaters in Amreli District, Gujarat. J Geol Soci India 33:450-456

Saxena VK, Ahmed S (2003) Inferring the chemical parameters for the dissolution of fluoride in groundwater. Environ Geol 43:731-736

Shaji E, Bindu Viju J, Thambi DS (2007) High fluoride in groundwater of Palghat District, Kerala. Curr Sci 92:240-245

Shortt HE, McRobert GR, Barnard TW, Mannadinayer AS (1937) Endemic fluorosis in Madras Presidency, India. Ind J Med Res 25:553-561

Singaraja C, Chidambaram S, Anandhan P, Prasanna MV, Thivya C, Thilagavathi R (2013) A study on the status of fluoride ion in groundwater of coastal hard rock aquifers of south India. Arab J Geosci 6:4167-4177

Sreedevi PD, Ahmed S, Made B, Ledoux E, Gandolfi JM (2006) Association of hydrological factors in temporal variations of fluoride concentration in a crystalline aquifer in India. Environ Geol 50:1-11

Srinivasamoorthy K, Chidambaram S, Vasanthavigar M (2008) Geochemistry of fluorides in Salem district, Tamilnadu, India. J Envron Geol 16:25

Srinivasamoorthy K, Vijayaraghavan K, Vasanthavigar M, Sarma Subramanya, Chidambaram S, Paluchamy A, Manivannan R (2012) Assessment of groundwater quality with special emphasis on fluoride contamination in crystalline bed rock aquifers of Mettur region, Tamilnadu, India. Arab J Geosci 5:83-94
Stallard RF, Edmond JM (1983) Geochemistry of the Amazon River-the influence of the geology and weathering environment on the dissolved load. J Geophy Res 88:9671-9688

Stumm W, Morgan JJ (1996) Aquatic chemistry. Wiley-Interscience, New York

Subba Rao N (2002) Geochemistry of groundwater in parts of Guntur District, Andhra Pradesh, India. Environ Geol 41:552-562

Subba Rao N (2003) Groundwater quality-focus on fluoride concentration in rural parts of Guntur District, Andhra Pradesh, India. Hydrol Sci J 48:835-847

Subba Rao N (2009) Fluoride in groundwater, Varaha River Basin, Visakhapatnam District, Andhra Pradesh, India. Environ Monit Assess 152:47-60

Subba Rao N (2011) High-fluoride groundwater. Environ Monit Assess 176:637-645

Subba Rao N (2014) Development and management of groundwater resources in a coastal region: a study from Prakasam District, Andhra Pradesh. In: Presented at 7th DST PAC-WTI on 10th January 2014. IIT, Bhubaneswar

Subba Rao N, John Devadas D (2003) Fluoride incidence in groundwater in an area of Peninsular India. Environ Geol 45:243-253

Subba Rao N, Rao AT (2003) Fluoride in groundwater in a developing area of Guntur District, Andhra Pradesh, India. J Appl Geochem 5:99-100

Subba Rao N, Krishna Rao G, John Devadas D (1998a) Variation of fluoride in groundwater of crystalline terrain. J Environ Hydrol $6: 1-5$

Subba Rao N, Prakasa Rao J, Nagamalleswara Rao B, Niranjan Babu P, Madhusudhana Reddy P, John Devadas D (1998b) A preliminary report on fluoride content in groundwater of Guntur Area, Andhra Pradesh, India. Curr Sci 75:887-888

Subba Rao N, Subrahmanyam A, Babu Rao G (2012) Fluoridebearing groundwater in Gummanampadu sub-basin, Guntur District, Andhra Pradesh, India. Environ Earth Sci 70:575-586

Subba Rao N, Vidyasagar G, Surya Rao P, Bhanumurthy P (2014a) Chemistry and quality of groundwater in a coastal region of Andhra Pradesh. Appl Water Sci (accepted), India

Subba Rao N, Vidyasagar G, Surya Rao P, Bhanumurthy P (2014b) Assessment of hydrogeochemical processes in a coastal region: application of multivariate statistical model. J Geol Soc India $84: 494-500$

Sujatha D (2003) Fluoride levels in the groundwater of the south eastern part of Ranga Reddy District, Andhra Pradesh, India. Environ Geol 44:587-591

Sumalatha S, Ambika SR, Prasad SJ (1999) Fluoride contamination status of groundwater in Karnataka. Curr Sci 76:730-734

Surya Rao P, Subba Rao N, Dinakar A (2015) Fluoride in the groundwater in Etcherla Mandal, Srikakulam District, Andhra Pradesh. J Geosci Res 1:53-59

Susheela AK (1999) Fluorosis management programme in India. Curr Sci 77:1250-1256

Todd DK (1980) Groundwater hydrology. Wiley, New York

USPHS (1987) Drinking water standards. United States Pubic Health Services Publication, Washington, DC

Vikas C, Kushwaha RK, Pandit MK (2009) Hydrochemical status of groundwater in district Ajmer (NW India) with reference to fluoride distribution. J Geol Soc India 73:773-784

WHO (2008) Guidelines for drinking water quality. World Health Organization, Geneva

Wodeyar BK, Sreenivasan G (1996) Occurrence of fluoride in the groundwater and its impact in Peddavankahalla Basin, Bellary District, Karnataka, India-a preliminary study. Curr Sci 70:71-74 